\title{
СПЕЦИФІКА СЕМАНТИКО-СИНТАКСИЧНОЇ ОРГАНІЗАЦЇ̈ БЕЗОСОБОВИХ ТА ІНФІНІТИВНИХ ОДНОСКЛАДНИХ КОНСТРУКЦІЙ
}

Межов О. Г. Специфіка семантико-синтаксичної організації безособових та інфінітивних односкладних конструкцій

У статті здійснено комплексний семантико-граматичний аналіз безособових та інфінітивних односкладних речень сучасної української мови. Визначено місце безособових та інфінітивних речень у системі односкладних конструкцій. Схарактеризовано їхню семантико-синтаксичну організацію, лексичне наповнення. Встановлено засоби вираження семантичних компонентів, їх співвідношення 3 членами формально-синтаксичної структури речення. Виділено синтаксичні зв'язки i семантико-синтаксичні відношення в односкладних реченнях. Простежено синтаксичну синонімію односкладних і двоскладних конструкцій.

Ключові слова: безособові речення, інфінітивні речення, предикат, дієслово, відмінок, прислівник, іменник, член речення.

Межов А. Г. Специфика семантико-синтаксической организации безличных и инфинитивных односоставных конструкций

В статье осуществлен комплексный семантико-грамматический анализ безличных и инфинитивных односоставных предложений современного украинского языка. Определено место безличных и инфинитивных предложений в системе односоставных 
конструкций. Описано их семантико-синтаксическую организацию, лексическое наполнение. Установлены средства выражения семантических компонентов, их соотношение с членами формально-синтаксической структуры предложения. Выделены синтаксические связки и семантико-синтаксические отношения в односоставных предложениях. Прослежено синтаксическую синонимию односоставных и двусоставных конструкций.

Ключевые слова: безличные предложения, инфинитивные предложения, предикат, глагол, падеж, наречие, существительное, член предложения.

Mezhov O. G. Specificity semantic-syntactical organization impersonal and infinitive of sentences

In this paper a complex semantic-grammatical analysis impersonal and infinitive sentences by modern Ukrainian language. Place impersonal and infinitive sentences in composite structures already defined. Semantic-syntactic organization impersonal and infinitive of sentences, lexical filling determined. Means of expressing semantic components, their relationships with members of the formal syntactic structure of sentences is established. Syntactic relations and semantic-syntactic relations in sentences highlighted. Syntactic synonymy structures traced.

Key words: impersonal sentences, infinitive sentences, predicate, verb, case, prepositional case, adverb, noun, parts of the sentence.

На відміну від двоскладних речень, у яких граматичний центр утворюють два компоненти - підмет і присудок, специфіку формальнограматичної структури односкладних конструкцій становить наявність тільки одного головного члена речення, не диференційованого на підмет або присудок. На семантико-синтаксичному рівні односкладного речення цей головний член корелює із предикатною синтаксемою (рідше суб'єктно-предикатною чи суб'єктно-адресатно-предикатною), вираженою безособовою дієслівною, прислівниковою формою, інфінітивом, номінативом або вокативом. Відповідно до морфологічної якості головного члена можна насамперед виділити дієслівні, прислівникові та іменникові односкладні речення [4, с. 72], кожне з яких має специфічну внутрішню семантико-синтаксичну організацію. Синтаксична традиція розрізняє безособові, інфінітивні та номінативні односкладні речення [10].

Об’єктом пропонованого дослідження обрано безособові та інфінітивні односкладні речення. Незважаючи на тривалу історію їх вивчення у працях О. О. Шахматова [11], О. М. Пєшковського [7], Л. А. Булаховського [2], В. В. Бабайцевої [1], Т. П. Ломтєва [6], М. Я. Плющ [8], П. С. Дудика [10], I. І. Слинька [9], І. Р. Вихованця [3; 4], К. Г. Городенської [5] та ін., ці конструкції не втратили своєї актуальності й потребують грунтовнішого опрацювання саме в семантико-синтаксичному плані. Мета статті здійснити комплексний семантико-граматичний аналіз безособових та інфінітивних односкладних речень сучасної української мови. Для досягнення цієї мети потрібно розв'язати такі завдання: визначити місце безособових та інфінітивних речень у системі односкладних конструкцій; схарактеризувати їхню семантико-синтаксичну організацію, лексичне наповнення; встановити 
засоби вираження семантичних компонентів, їх співвідношення з членами формально-синтаксичної структури речення; виділити синтаксичні зв'язки і семантико-синтаксичні відношення в реченнях; простежити синтаксичну синонімію односкладних і двоскладних конструкцій.

Найтиповішу групу односкладних речень становлять безособові. Безособові речення - це такі утворення, у яких виражено стан (ознаку) чи дію, що виникають та існують незалежно від носія стану і виконавця дії [1, с. 53]. У центрі таких конструкцій - дієслівні предикати, вживані у формі третьої особи однини теперішнього й майбутнього часу (або середнього роду в минулому часі та умовному способі) і поєднані підрядним зв'язком керування 3 іменником у непрямому відмінку, якщо такий $є$ в реченні. Через те поряд з терміном «безособове речення» існує термін «одноособове речення». На думку, І. Р. Вихованця, термін «безособові дієслова» неадекватно відбиває семантико-граматичну природу цих дієслівних одиниць, адже вони мають стосунок до граматичної особи i виділяються на основі $\mathrm{i}$ семантичних, і формальних відмінностей. Вказана група дієслів стосується третьої особи однини, а тому такі дієслова варто кваліфікувати як одноособові, а не безособові [3, с. 195]. У безособових реченнях можуть функціонувати в ролі головного члена і предикативні прислівники (слова категорії стану). Семантико-синтаксична структура елементарних безособових речень переважно двокомпонентна - iз предикатом i суб'єктом у давальному, знахідному, родовому або місцевому відмінках.

У безособових конструкціях давальний відмінок виражає найчастіше вторинну семантико-синтаксичну функцію суб'єкта стану. Непрямим відмінкам із суб'єктним значенням властива співвіднесеність їх із називним суб'єкта у двоскладних реченнях. Однак не можна ототожнювати суб'єктні синтаксеми, виражені називним і непрямими відмінками. Якщо зіставити називний суб'єкта дії і давальний суб'єкта, що грунтується на називному, то з функцією суб'єкта дії називного пов'язана семантикосинтаксична ознака активності, а з функцією давального - трансформована 3 активності ознака деміактивності [6, с. 171-197]. На ознаку пасивності давального суб'єкта в безособових реченнях звернув увагу ще О. О. Шахматов, який писав: «Носій стану, виражений давальним, - особа пасивна, дієслівна ознака, що спрямовується до неї, не досягає іiі» [11, с. 29]. Отже, давальний суб'єкта стану односкладних речень перебуває в синонімічних відношеннях із називним суб'єктним відмінком двоскладних конструкцій. У двоскладних реченнях суб'єкт (діяч) активний, а в односкладних безособових (одноособових) - пасивний. Конструкції з називним суб'єкта первинні, речення з давальним суб'єкта стану є наслідком різноманітних перетворень, трансформацій. «Такий давальний, - зазначає I. Р. Вихованець, переміщується із правобічної дієслівної позиції у лівобічну і певною мірою тяжіє до називного відмінка в суб’єктній функції» [3, с. 112]. Ця трансформація, 
на думку К. Г. Городенської, можлива лише за умови формально-граматичної нейтралізації суб’єктної синтаксеми називного відмінка базового двоскладного речення [5, с. 72-74], пор.: Мені й досі страшно (П. Загребельний) $\leftarrow \underline{Я ~} \check{u}$

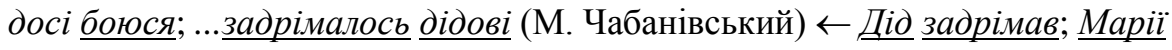
... стало спокійно $($ О. Іваненко $\leftarrow$ Марія стала спокійною.

У структурі безособових речень давальний суб'єкта може виражати особу, якій потенційно притаманна та або інша діяльність, але реалізується вона в предикаті як стан, що залежить від готовності / неготовності суб'єкта до дії або можливості / неможливості iі виконання. Такі семантично двокомпонентні речення є трансформами вихідних двоскладних конструкцій iз предикатами дії або процесу та називним суб'єктним відмінком, пор.:

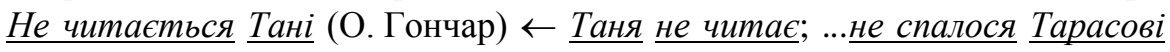
Григоровичу (3. Тулуб) $\leftarrow$ Тарас Григорович не спав. Заперечність дієслова (навіть із семантикою діi) у вихідному двоскладному реченні створює передумови для остаточного морфологічного закріплення значення стану в дієсловах, що виконують роль головного члена односкладних речень. Суб’єкт стану в давальному відмінку типовий для речень 3 дієсловами везіння чи невезіння (везти, таланити, фортунити, щуастити), напр.: Прямо-таки везло йому в изьому році (М. Стельмах); Мисливцям надзвичайно поталанило (З. Тулуб); Пофортунило Маркові (М. Стельмах); Ото не шастило чоловіку (Л. Костенко).

У конструкціях із дієсловами достатності / недостатності давальний відмінок виражає значення суб'єкта стану, особливість якого у відчутті фізичної або морально-психічної достатності / недостатності чого-небудь необхідного чи бажаного. Напр.: Терпимості завше нам бракувало (О. Гончар); Мені забракло мужності (М. Стельмах); Великій людині -а такою людиною й був В. Чумак - завжди вистачить часу для реалізації свого таланту (Д. Павличко); Україниям стачило слави запорізького козацтва, визвольних воєн під хоругвами Богдана Хмельницького на два з половиною століття... (В. Яворівський).

Активно вживані в українській мові односкладні речення з давальним суб’єкта стану та предикативними прислівниками (словами категорії стану). Такі конструкції є трансформами двоскладних речень з називним суб'єктним

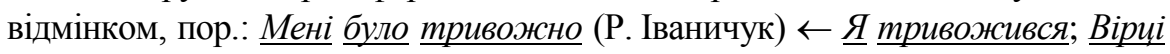
справді стало сумно (Б. Харчук) $\leftarrow$ Вірка справді стала сумна. Такі речення можуть не мати базового конкретного двоскладного формальнограматичного речення, напр.: Страшно було козакові (Ю. Мушкетик); Гнатові жарко (Григорій Тютюнник); Поетові справді моторошно (В. Стус). Їх кваліфікують як такі, що утворилися на основі загального стосунку до вихідної моделі двоскладних речень [3, с. 114-115; 5, с. 73-74], пор.: Opuci

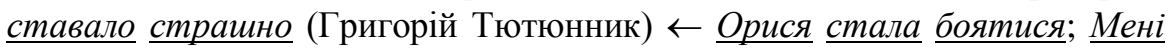

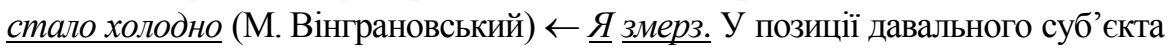


стану перебувають найчастіше іменники-назви істот, рідше - назви частин організму, напр.: Весело, легко стало Лаврінові (Ю. Мушкетик); Гандзі було тепло (М. Трублаїні); Ногам стало тепло (Б. Харчук).

Безособовий дієслівний предикат може керувати також формою знахідного відмінка. Знахідний відмінок суб'єкта стану поєднується з невеликою групою безособових дієслів, які виражають внутрішній фізичний стан особи (лихоманити, морозити, нудити, тіпати, трусити, трясти). Напр.: Ольгу занудило (В. Яворівський); $\ddot{I} \underline{i}$ [Діну] ... minaє (А. Дімаров); Підлітка ... трусило (А. Дімаров); Селім-Гірея морозило (Ю. Мушкетик). Такі конструкції є семантично елементарними: дієслівний предикат у них відкриває лише одну лівобічну валентну позицію для суб'єкта стану. Знахідний суб'єкта, як i знахідний об'єкта, характеризується семантико-синтаксичними ознаками субстанціальності, валентного зв'язку із предикатом, пасивності, фінальної спрямованості [3, с.91]. У розгляданих реченнях простежуємо не вихідність стану, а спрямованість останнього на суб'єкт.

У заперечних односкладних реченнях із предикатами відсутності / неіснування (нема, не було, не буде, не існує) вживається родовий суб'єктний відмінок. Такі конструкції вважають заперечними варіантами двоскладних речень буття з предикатами існування, наявності ( $\epsilon$, був, буде, існує) [9, с. 464]. Пор.: Давно не було дошів (П. Воронько) $\leftarrow$ Давно були домі; Немає грека. I немає скіфів. Немає тих скульптур (Л. Костенко)

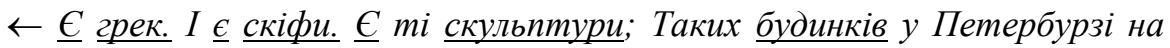
Невському нема (3. Тулуб) $\leftarrow$ Такі будинки $\underline{\epsilon}$ у Петербурзі на Невському;

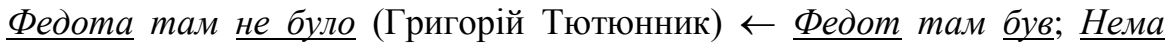
cпівия (Р. Іваничук) $\leftarrow$ Співець $\underline{\text { En }}$.

При предикатах, що виражають стан довкілля (тепло, холодно, жарко, душно, морозно, спекотно, тихо, вітряно, сніжно, безлюдно, затично, порожньо та ін.), у лівобічній суб'єктній позиції перебуває прийменниковий місцевий відмінок. Він перемістився 3 детермінантної (локативної) у прислівну (суб'єктну) позицію речення, заступивши давальний відмінок як основний засіб вираження суб'єктності в односкладних реченнях із предикативними прислівниками, напр.: $\underline{y} \underline{\text { cmeny }}$ було вітряно. Синтаксема у місцевому відмінку має синкретичний характер: вона виражає суб'єктно-

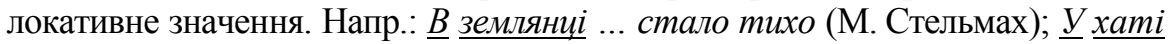

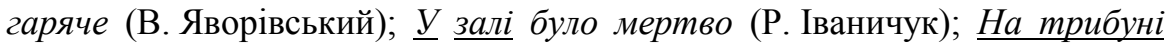

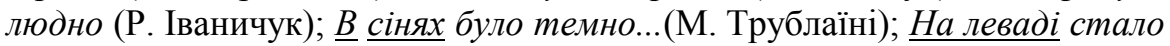
холодніше (М. Вінграновський); $\underline{B}$ лісі тихо (М. Трублаїні). Деякі конструкції 3 прийменниково-відмінковими формами трансформуються у речення 3

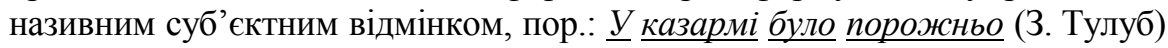

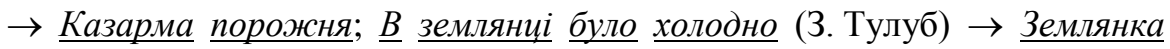

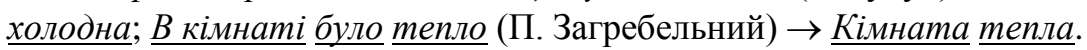


В інфінітивних конструкціях давальний суб'єкта має певні особливості. Інфінітивні речення спочатку розглядали серед безособових (Ф. І. Буслаєв, О. О. Потебня, Д. М. Овсянико-Куликовський, у пізніший час - С. М. ГалкінаФедорук, Л. А. Булаховський та ін.). Однак уже О. М. Пєшковський виділив їх в окремий тип і дав назву «інфінітивні речення». Підставою для відокремлення цих речень від безособових був той факт, що інфінітив у них виступає «сам по собі, поза його відношеннями до власне дієслова або дієслівної зв'язки» [7, с. 347]. До інфінітивних О. М. Пєшковський зарахував тільки такі речення, у яких є так званий незалежний інфінітив, тобто інфінітив без допоміжного дієслова бути, предикативів треба, можна тощо. Такий інфінітив формально не підпорядковується іншому членові речення і має найбільше змістове навантаження. Багато дослідників услід за О. М. Пєшковським вважають інфінітивними лише речення з непоширеним незалежним інфінітивом. Більшу пояснювальну силу має відомий у сучасній українській граматиці погляд, згідно 3 яким до інфінітивних слід зараховувати не тільки речення з інфінітивами простої форми, а й складеної [4; 9]. Дія в інфінітивному реченні співвідноситься 3 діячем, вираженим іменником або його еквівалентом зі значенням діючої особи в давальному відмінку. Давальний приінфінітивний здавна вживається в слов'янських мовах для оформлення назви реального суб'єкта дії чи стану [2, с. 276].

Інфінітив в односкладному реченні самостійно не може виражати значення особи. У цьому йому «допомагає» відмінкова форма - давальний відмінок суб'єкта. На відміну від безособових речень, у яких суб'єкт може бути представлений, крім давального відмінка, іншими непрямими відмінками, в інфінітивних реченнях у позиції суб'єкта функціонує тільки давальний відмінок. Один 3 моментів, на основі яких варто розглядати інфінітивні речення як окремий тип односкладних (а не різновид безособових), $\epsilon$ логічний зв'язок дії з визначеною або узагальненою особою.

Інфінітивні речення традиційно поділяють на два основні різновиди: a) із простим інфінітивним головним членом без частки би(б), які виражають

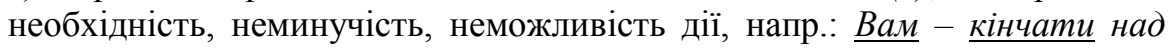

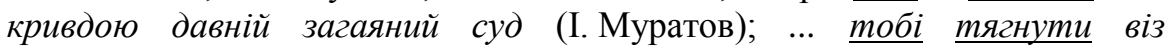
(В. Симоненко); б) із простим інфінітивним головним членом із часткою би (б), які передають бажаність дії, побоювання чи застереження 3 приводу здійснення/нездійснення дії, оцінку здатності або схильності до дії тощо [10], напр.: Нам би знову зустрітися через тисячу літ... (В. Гей); Мені б уже на печі або призьбі кахикати потроху, а не головувати (М. Стельмах); Мені б тільки поспівати (О. Гончар); Федору б передачу понести (Б. Харчук). Допоміжні модальні слова, у яких міститься предикатне значення стану, мають нульове вираження. Основне змістове навантаження припадає на інфінітив. Подібні інфінітивні речення співвідносяться із двоскладними, легко трансформуються в них, пор.: 


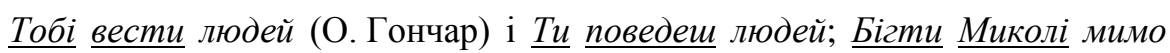
Ягорової хати... (О.Гончар) і Микола бігтиме мимо Ягорової хати. Давальний відмінок у таких конструкціях виражає значення потенційного суб'єкта дії, йому властива ознака активності, тому у позиції давального суб'єкта виступають здебільшого назви людей, зрідка - інших істот.

Речення зі складеним головним членом виражені інфінітивом повнозначного дієслова й допоміжними модальними словами типу варто, можна, потрібно, треба, необхідно і под. зі зв'язкою бути у відповідній формі та дієсловами типу доводиться, хочеться. Такі конструкції пов'язані з двоскладними реченнями синонімічними відношеннями. Отже, транспозиція називного відмінка суб'єкта дії двоскладних речень у давальний суб'єкта односкладних можлива через введення названих вище допоміжних слів, які створюють модальність вимушеності, ймовірності або бажаності у предикатів стану, з одного боку, і знижують ранг предикатів дії, перетворюючи їх на предикати стану-ймовірної дії, з другого [3, с. 115], пор.: Отож на порозі третього тисячоліття землянам треба багато чого осмислити (3 газети) $\leftarrow$ Отож на порозі третього тисячоліття земляни багато чого осмислюють; Нашій державі потрібно проводити за кордоном широку рекламну діяльність (3 газети) $\leftarrow$ Наша держава проводить за кордоном широку рекламну діяльність; Прабабиі Марфі просто хотілося попліткувати (В. Яворівський) $\leftarrow$ Прабабка Марфа пліткує. Давальний відмінок у поданих реченнях передає ускладнене значення суб'єкта стану - потенційної дії.

Нерідко з предикативними прислівниками (аналітичними дієсловами стану) функціонально зближується інфінітив, включаючись у вираження предикативної ознаки, приписуваної суб'єктові, напр.: Мені сумно писати иі рядки (3 газети); Нелегко праџювати Володимиру Забаштанському (Б. Олійник). Значення давального тут також ускладнене (суб'єкт стану - потенційної діі).

В інфінітивних та безособових реченнях давальний суб'єкта може бути опущений (лексично не виражений), тоді суб'єкт розуміють узагальнено. На думку М. Я. Плющ, «....суб’єктне значення у випадках опущення словоформи давального суб'єкта повністю не нейтралізується, воно присутнє з відтінком узагальненості» [8, с. 100]. Напр.: Необхідно тепер щукати позитивне в історії і сучасності (3 газети); Треба було б їх затримати (М. Трублаїні); $\underline{\mathrm{He}}$ спалося (Ю. Мушкетик); Холодно зробилося (В. Барка).

Отже, безособові та інфінітивні речення, активно вживані в різних стилях сучасної української мови, формують центр системи односкладних речень. Дієслівний, прислівниковий або інфінітивний головний член таких конструкцій співвіднесений із присудком двоскладного речення. Елементарну семантико-синтаксичну структуру безособових та інфінітивних речень утворюють предикат і суб'єкт у непрямому відмінку, який нерідко корелює iз називним суб'єкта двоскладного речення. Перспективним у цьому напрямі є дослідження комунікативного членування односкладних речень. 


\section{Література}

1. Бабайцева В. В. Односоставные предложения в современном русском языке : [монография] / В. В. Бабайцева. - М. : Просвещение, 1968. - 160 с.

2. Булаховський Л. А. Питання синтаксису простого речення в українській мові / Л. А. Булаховський // Дослідження з синтаксису української мови. - К. : Вид-во АН УРСР, 1958. - С. 11-43.

3.Вихованець І.Р. Система відмінків української мови : [монографія] / I. Р. Вихованець. - К. : Наук. думка, 1987. -232 с.

4.Вихованець I. Р. Нариси 3 функціонального синтаксису української мови : [монографія] / І. Р. Вихованець. - К. : Наук. думка, 1992. - 222 с.

5.Городенська К. Г. Деривація синтаксичних одиниць : [монографія] / К. Г. Городенська. - К. : Наук. думка, 1991. - 192 с.

6. Ломтев Т. П. Предложение и его грамматические категории : [монография] / Т. П. Ломтев. - М. : Изд-во МГУ, 1972. - 197 с.

7.Пешковский А. М. Русский синтаксис в научном освещении / А. М. Пешковский. - [8-е изд., доп.]. - М. : Языки славянской культуры, 2001. -510 с. 8.Плющ М. Я. Категорії суб'єкта і об'єкта в структурі простого речення : [навч. посіб.] / М. Я. Плющ. - К. : Вища шк., 1986. -175 с.

9.Слинько I. I. Синтаксис сучасної української мови : проблемні питання : [навч. посіб.] / І. І. Слинько, Н. В. Гуйванюк, М. Ф. Кобилянська. - К. : Вища шк., 1994. - 670 с.

10. Сучасна українська літературна мова. Синтаксис / [за заг. ред. І. К. Білодіда]. К. : Наук. думка, 1972. - 515 с.

11. Шахматов А. А. Синтаксис русского языка / А. А. Шахматов ; [вступ. ст. Е. В. Клобуков ; ред. и коммент. Е. С. Истомина]. -3-е изд. - М. : УРСС, 2001. - 620 с. 